\title{
ENHANCEMENT OF Beaucarnea recurvata LEM. GROWTH BY SOME GROWTH REGULATORS
}

\author{
(Received: 20.10. 2008)
}

\author{
By \\ S. M. K. Abdel - Wahid and S. G. Sweify \\ Ornamental Plants and Landscape Gardening Department, Horticulture Research Institute, \\ Agricultural Research Center, Giza, Egypt.
}

\begin{abstract}
The response of Beaucarnea recurvata plants to the application of gibberellic acid $\left(\mathrm{GA}_{3}\right)$ and benzyladenine (BA) as a soil drench in a plastic house was studied during the two successive seasons of 2005 / 2006 and 2006 / 2007 at the nursery of Ornamental Plants Research and Landscape Gardening Department, Horticultural Research Institute, Agricultural Research Center, Giza, Egypt. The concentrations used were 200, 300 or 500 ppm for $\mathrm{GA}_{3}$ and 50, 100 or $200 \mathrm{ppm}$ for $\mathrm{BA}$ as well as untreated plants. The results reveal that using $\mathrm{GA}_{3}$ at $200 \mathrm{ppm}$ increased the stem diameter, leaf width, carotenoids content and total carbohydrates percentage in the leaves. Increasing the level of $\mathrm{GA}_{3}$ to $300 \mathrm{ppm}$ produced the heaviest fresh and dry weights of leaves. The concentration of $500 \mathrm{ppm}$ of $\mathrm{GA}_{3}$ increased the plant height, number of leaves / plant and $\mathrm{P}$ percentage in the leaves.

Also, the data indicate that BA at $50 \mathrm{ppm}$ increased leaf length and chlorophyll (a) content in the leaves. The concentration of $100 \mathrm{ppm}$ BA caused an increase in potassium percentage in the leaves. However the concentration of $200 \mathrm{ppm}$ resulted in the least number of leaves/ plant, fresh and dry weights of leaves, chlorophyll (b) and total chlorophylls content in the leaves.

So, to accelerate the growth of Beaucarnea recurvata plant it should be treated with $\mathrm{GA}_{3}$ at the rate of $400 \mathrm{ppm}$ as a soil drench.
\end{abstract}

Key words: Beaucarnea recurvata, benzyladenine (BA), gibberellic acid $\left(G A_{3}\right)$.

\section{INTRODUCTION}

Beaucarnea recurvata Lem. "Syn. Nolina recurvata Hemsl (Lem.)Hemsl."., Fam. Asparagaceae is a native to Mexico, in semidesertic areas. It is often called the "Ponytail palm" or "Bottle palm" although it is not a true palm. It is related to the yuccas and century plants. The plants are relatively slow growing. In nature, they will reach about $10 \mathrm{~m}$ in height with a base about $4 \mathrm{~m}$ across. In containers, they will only reach about $2.5 \mathrm{~m}$ in height. The plant usually has one stem until it reaches $90 \mathrm{~cm}$ tall, except if the main stem is damaged. Ponytail palm grows well in sun or semi-shade. It is hardy and drought resistant. It makes a large and handsome houseplant, doing well even in rooms with air conditioning as long as it has bright light. It is a good specimen plant for a rock garden in a dry, warm climate. It does well even in rainy climates along as the soil is sandy and extremely well drained. It is often sold as potted plant for the interesting appearance of its swollen base, which is in fact an adaptation for storing water during times of drought. It can store water up to one year (Staples and Herbst, 1996).

Hormones play a vital role in the control of growth within the plant as a whole and also within individual organs (Wareing and Phillips, 1973). Gibberellin is a naturallyoccurring plant growth regulator. It is a completely natural, organic substance that is present in many plants, and in fact is essential to certain life-processes in many plants (Salisbury and Ross, 1992). Active gibberellins show many physiological effects, each depending on the type of gibberellin present as well as the species of plant. Also, their effects are highly dependant on its 
concentration and stage of plant growth. Application of gibberellin can stimulate the stems of dwarf plants to additional growth by stimulating cell division and elongation (Raven et al. 1992).

Benzyladenine (BA) is a synthetic cytokinin effective in promoting elongation of inhibited buds (Cline, 1988). Cytokinin plays an important role in many physiological and developmental processes in the plant, such as cell division, regulation of shoot and root growth, stress response and pathogen resistance (Mok and Mok, 2001). They also participate in cell enlargement and tissue differentiation. Among the hormones, cytokinins have a unique characteristic in that they can be a structural component of RNA (Leopold and Kriedmann, 1980). Cytokinins retard senescence and chlorophyll degradation in aging leaf tissues. They interact with auxins in the control of apical dominance and lateral branching and the root-shoot ratio in intact plants (Srivastava, 2002)

The effect of $\mathrm{GA}_{3}$ and BA on the growth of various plants was studied by many investigators. Dwivedi et al. (1999) on strawberry noticed that $\mathrm{GA}_{3}$ at $50 \mathrm{ppm}$ resulted in the maximum leaf number. Farid $e t$ al. (1999) stated that foliar application of kinetin at $50 \mathrm{ppm}$ increased fresh and dry weight of sweet marjoram. Total carbohydrates, chlorophyll a, b contents as well as N, P and K percentage were increased due to the application of kinetin. Salama et al. (2002) stated that spraying fennel plants with $\mathrm{GA}_{3}(100$ or $200 \mathrm{ppm})$ and kinetin $(10$ or 20 ppm) increased plant height, number of leaves, fresh and dry weights of fennel shoots. Kinetin increased stem diameter, while $\mathrm{GA}_{3}$ decreased it. Farahat et al. (2002) on fennel found that BA at 50 or $100 \mathrm{ppm}$ increased significantly plant height, chlorophyll a, total chlorophylls as well as $\mathrm{N}, \mathrm{P}$ and total carbohydrate contents. Abdel-Wahid and Manoly (2003) mentioned that $\mathrm{GA}_{3}$ at 100 ppm increased plant height, leaf length and width as well as $\mathrm{P}$ content in the leaves of Ficus benjamina. The concentration of 50 ppm increased the total carbohydrates in the leaves, while $150 \mathrm{ppm}$ increased $\mathrm{N} \%$ in the leaves and $200 \mathrm{ppm}$ increased stem diameter. Hussien (2004) found that supplying Iris plants with BA at 10 or $20 \mathrm{ppm}$ significantly increased the plant height and fresh weight of leaves, total carbohydrates and $\mathrm{N} \%$ in the leaves. BA at $10 \mathrm{ppm}$ increased the leaf formation. Ahmed et al. (2005) on Peperomia obtusifolia indicated that $\mathrm{GA}_{3}$ at $400 \mathrm{ppm}$ resulted in the tallest plants with the heaviest fresh and dry weights and the thickest stem diameter. While, the concentration of 200 ppm increased leaf length and width. Eissa (2007) found that spraying Pelargonium zonal with BA at 10 or $20 \mathrm{ppm}$ increased plant height, fresh weight of vegetative parts, chlorophyll b, total chlorophylls and total sugars content in the leaves. Mahmoud (2007) noticed that spraying Chasmanthe aethiopica with kinetin at 25, 50 or $75 \mathrm{ppm}$ improved plant height and fresh and dry weights of leaves.

This work was carried out to investigate the effect of $\mathrm{GA}_{3}$ and $\mathrm{BA}$ on the vegetative growth and chemical constituents of Beaucarnea recurvata plants.

\section{MATERIALS AND METHODS}

A pot experiment was conducted in a plastic house at the Ornamental Nursery of Ornamental Plants Research and Landscape Gardening Department, Horticulture Research Institute, Agricultural Research Center, Giza, Egypt, during the two successive seasons of 2005 / 2006 and 2006 / 2007 to study the effect of gibberellic acid $\left(\mathrm{GA}_{3}\right)$ and benzyladenine (BA) on the vegetative growth and chemical constituents of Beaucarnea recurvata plants.

On March $20^{\text {th }}$ in the two seasons of 2005 / 2006 and 2006 / 2007 homogenous plants were transplanted in plastic pots $(20 \mathrm{~cm}$ diameter) filled with a mixture of clay and sand $(1: 1 \mathrm{v} / \mathrm{v})$. The plants were fertilized with NPK at the ratio of 1: 1: 1 at the rate of $3 \mathrm{~g} /$ pot as basic. The application started on May $4^{\text {th }}$ and repeated every 2 months till the termination of the experiment. The fertilizers used were ammonium sulphate $(20 \% \mathrm{~N})$, calcium superphosphate $\left(\begin{array}{lll}15.5 \% & \mathrm{P}_{2} \mathrm{O}_{5}\end{array}\right)$ and potassium sulphate $\left(\begin{array}{llll}48 & \% & \mathrm{~K}_{2} \mathrm{O}\end{array}\right)$. The concentrations used of growth regulators were $0,200,300$ or $500 \mathrm{ppm}$ for $\mathrm{GA}_{3}$ and 0,50 ,

Table (A): Mechanical analysis of the soil.

\begin{tabular}{|c|c|c|c|}
\hline Sand \% & Silt \% & Clay \% & Soil texture \\
\hline 38.30 & 32.51 & 29.19 & Sandy clay \\
\hline
\end{tabular}

100 or $200 \mathrm{ppm}$ for BA. Thirty five $\mathrm{ml}$ of each concentration were added to each plant 
Table (B): Chemical analysis of the soil.

\begin{tabular}{|c|c|c|c|c|c|c|c|}
\hline \multicolumn{2}{|c|}{ Cations Meq / L } & \multicolumn{2}{|c|}{ Anions Meq / L } & & & & \\
\hline $\mathrm{Na}^{+}$ & 1.15 & $\mathrm{HCO}^{-}$ & 2.11 & $\mathrm{pH}$ & 8.12 & $\mathrm{~N}$ & $467 \mathrm{ppm}$ \\
\hline $\mathrm{K}^{+}$ & 0.32 & $\mathrm{SO}^{-}$ & 0.45 & E.C. & $\begin{array}{c}1.38 \\
\text { mmohs }\end{array}$ & $\mathrm{P}$ & $35.0 \mathrm{ppm}$ \\
\hline $\mathrm{Ca}^{++}$ & 9.21 & $\mathrm{Cl}^{-}$ & 0.64 & \multirow{2}{*}{$\begin{array}{l}\text { Organic } \\
\text { matter }\end{array}$} & \multirow{2}{*}{0.34} & $\mathrm{~K}$ & $553.0 \mathrm{ppm}$ \\
\hline $\mathrm{Mg}^{++}$ & 6.20 & & & & & & \\
\hline
\end{tabular}

as a soil drench every two months during the period of the investigation. The application started on June the $4^{\text {th }}$. The plants were irrigated whenever required. The plants were left to grow for 12 month every season. Data were taken in the following May in the two seasons.

The mechanical and chemical analyses of the soil used in the experiment are shown in Tables (A) and (B). These analyses were conducted before planting in both seasons.

At the end of the experiment of each season the following data were recorded:

\subsection{Vegetative growth}

1- Plant height $(\mathrm{cm})$.

2- Stem diameter $(\mathrm{mm})$ at the middle of the stem.

3- Number of leaves / plant.

4- Leaf length $(\mathrm{cm})$.

5- Leaf width (mm).

6- Fresh and dry weights of leaves (g).

\subsection{Chemical constituents}

Pigment contents in the leaves, total carbohydrates percentage and elements $(\mathrm{N}, \mathrm{P}$ $\& \mathrm{~K})$ in the leaves were estimated. The chemical analyses were performed as follows:

1- Pigment content determination was carried out in the fresh leaves according to Saric et al. (1967).

2- Total carbohydrates in the leaves were determined according to Herbert et al. (1971).

3- Nitrogen percentage was determined using micro-Kjeldahl method (Pregl, 1945 and Piper, 1947).

4- Phosphorus content was determined according to Troug and Meyer (1939).

5- Potassium content was carried out by using operation chart for Shimadzu Atomic Absorption Flame Spectrophotometer AA-646 with a boiling air-acetylene burner and recorded readout.

The layout of the experiment was a randomized complete blocks with 7 treatments, each treatment contained three replicates. Each replicate consisted of five plants, i.e. 15 plants in each treatment. The statistical analysis was carried out according to Snedecor and Cochran (1982). L.S.D. at 0.05 was used to compare the differences between means of treatments.

\section{RESULTS AND DISCUSSION 3.1. Vegetative growth}

The data on the vegetative growth are presented in Tables (1) and (2).

\subsubsection{Plant height}

The data indicate that in the two seasons, both $\mathrm{GA}_{3}$ and $\mathrm{BA}$ significantly increased the plant height over the control. $\mathrm{GA}_{3}$ treatments were more effective in this concern than BA. Increasing the concentration of $\mathrm{GA}_{3}$ gradually increased the plant height, while increasing BA more than $100 \mathrm{ppm}$ decreased it. The tallest plants $(107.56$ and $120.28 \mathrm{~cm}$, in the first and second seasons, respectively) were found in the plants treated with $\mathrm{GA}_{3}$ at 500 ppm. However, the shortest ones were those of control plants $(81.88$ and $78.33 \mathrm{~cm}$, in the first and second seasons respectively). The promotive effect of $\mathrm{GA}_{3}$ on plant height may be a result of both larger number of cells formed and elongation of individual cells (Sacks, 1961). Also, Runkova (1977) found that $\mathrm{GA}_{3}$ increased plant height by increasing the leaf content of active indolic compounds and accelerated the synthesis of IAA. Moreover, cytokinins affected both cell division and enlargement (Arteca, 1996), in addition, he added that exogenous application of cytokinins promotes cell expansion and enlargement due to water uptake caused by a decrease in the osmotic potential.

\subsubsection{Stem diameter}

The results show that in both seasons, treating the plants with growth regulators increased the stem diameter over the control, same as in plant height. Application of $\mathrm{GA}_{3}$ at $200 \mathrm{ppm}$ resulted in the thickest stems (10.77 and $22.12 \mathrm{~mm}$, respectively) in the two seasons. While, the thinnest stems (8.16 and $13.88 \mathrm{~mm}$, in the first and second seasons, respectively) were those of the control plants. Increasing $\mathrm{GA}_{3}$ rate led to a gradual decrease in stem diameter in both seasons. Similar 
results were obtained by Abdel-Wahid and Manoly (2003) who found that $\mathrm{GA}_{3}$ at 200 ppm increased stem diameter of Ficus benjamina. Also, Ahmed et al. (2005) on Peperomia obtusifolia indicated that $\mathrm{GA}_{3}$ at $400 \mathrm{ppm}$ resulted in the thickest stem diameter.

\subsubsection{Number of leaves / plant}

The data on the number of leaves / plant show that, in the two seasons all the treatments increased the number of leaves / plant over the control except the concentration of 200 ppm BA. Increasing $\mathrm{GA}_{3}$ concentration gradually increased the leaf number, while increasing BA rate gradually decreased it. Supplying the plants with $\mathrm{GA}_{3}$ at $500 \mathrm{ppm}$ resulted in the greatest number of leaves / plant in both seasons (48.61 and 35.67 leaves / plant), same as in plant height. Meanwhile, the plants treated with BA at $200 \mathrm{ppm}$ had the least number of leaves / plant (31.00 and 25.00 leaves/ plant, in the first and second seasons, respectively). These results are in accordance with those obtained by Nofal $e t$ al. (1998) who mentioned that spraying kinetin at the levels of 25,50 or $75 \mathrm{ppm}$ increased the mean number of leaves. Dwivedi et al. (1999) on strawberry noticed that $\mathrm{GA}_{3}$ at $50 \mathrm{ppm}$ resulted in the maximum leaf number. Salama et al. (2002) stated that spraying fennel plants with $\mathrm{GA}_{3}$ (100 or $200 \mathrm{ppm}$ ) and kinetin (10 or $20 \mathrm{ppm}$ ) increased number of leaves, Hussien (2004) found that supplying Iris plants with $\mathrm{BA}$ at $10 \mathrm{ppm}$ significantly increased the leaf formation.

\subsubsection{Leaf length}

From the Tables (1) and (2) it can be noticed that in both seasons, same as in plant height and stem diameter, all the treatments increased the leaf length over the control. The longest leaves $(67.32$ and $69.28 \mathrm{~cm}$, in the first and second seasons; respectively) were formed on the plants treated with BA at 50 ppm. The shortest ones $(47.18$ and $44.11 \mathrm{~cm}$, respectively) were those of the control plants. Raising $\mathrm{GA}_{3}$ or BA levels decreased the leaf length in the two seasons.

\subsubsection{Leaf width}

The data reveal that in both seasons all the treatments led to an increase in leaf width over the control. Same as in leaf length, increasing the concentration of $\mathrm{GA}_{3}$ or $\mathrm{BA}$ decreased the leaf width. The widest leaves (17.67 and $12.72 \mathrm{~mm}$ ) were found in the plants treated with $\mathrm{GA}_{3}$ at $200 \mathrm{ppm}$. The narrowest leaves (11.33 and $7.72 \mathrm{~mm})$ were found in the control plants. These results are in agreement with the findings of AbdelWahid and Manoly (2003) who indicated that $\mathrm{GA}_{3}$ at $100 \mathrm{ppm}$ increased leaf length and width. Ahmed et al. (2005) on Peperomia obtusifolia found that $\mathrm{GA}_{3}$ at $200 \mathrm{ppm}$ increased leaf length and width.

\subsubsection{Fresh and dry weight of leaves}

The data point out that in the two seasons, the heaviest fresh and dry weights of leaves were found due to the application of $\mathrm{GA}_{3}$ at $300 \mathrm{ppm}$. The values were 65.75 and $56.83 \mathrm{~g}$, respectively for the fresh weight and 15.79 and $13.97 \mathrm{~g}$, respectively for the dry weight. The plants treated with BA at 200 ppm had the lightest fresh and dry weights of leaves. The values were 43.38 and $31.87 \mathrm{~g}$, respectively for the fresh weight and 10.18 and $7.48 \mathrm{~g}$, respectively for the dry weight. The increasing effect on fresh and dry weights which was obtained with $\mathrm{GA}_{3}$ may be attributed to the stimulating effect of $\mathrm{GA}_{3}$ on

(1): Effect of $\mathbf{G A}_{3}$ and $\mathbf{B A}$ on the vegetative growth of Beaucarnea recurvata Lem. plant during the first season $(2005$ / 2006).

\begin{tabular}{|l|c|c|c|c|c|c|c|}
\hline \multicolumn{1}{|c|}{ Treatments } & $\begin{array}{c}\text { Plant } \\
\text { height } \\
(\mathbf{c m})\end{array}$ & $\begin{array}{c}\text { Stem } \\
\text { diameter } \\
(\mathbf{m m})\end{array}$ & $\begin{array}{c}\text { Number } \\
\text { of leaves / } \\
\text { plant }\end{array}$ & $\begin{array}{c}\text { Leaf } \\
\text { length } \\
(\mathbf{c m})\end{array}$ & $\begin{array}{c}\text { Leaf } \\
\text { width } \\
(\mathbf{m m})\end{array}$ & $\begin{array}{c}\text { Leaves } \\
\text { fresh } \\
\text { weight } \\
\text { (g) }\end{array}$ & $\begin{array}{c}\text { Leaves } \\
\text { dry } \\
\text { weight } \\
(\mathbf{g})\end{array}$ \\
\hline Control & 81.88 & 8.16 & 35.67 & 47.18 & 11.33 & 52.40 & 12.75 \\
$\mathrm{GA}_{3}$ 200 ppm & 99.22 & 10.77 & 40.72 & 63.27 & 17.67 & 59.66 & 13.86 \\
$\mathrm{GA}_{3}$ 300 ppm & 103.17 & 9.85 & 46.56 & 59.13 & 15.78 & 65.75 & 15.79 \\
$\mathrm{GA}_{3}$ 500 ppm & 107.56 & 8.54 & 48.61 & 54.81 & 14.20 & 59.40 & 13.82 \\
$\mathrm{BA} 50 \mathrm{ppm}$ & 93.78 & 9.76 & 39.56 & 67.32 & 15.11 & 48.64 & 12.21 \\
$\mathrm{BA}$ 100 ppm & 95.67 & 8.56 & 36.86 & 53.93 & 14.56 & 51.49 & 12.58 \\
BA 200 ppm & 89.33 & 8.28 & 31.00 & 51.91 & 12.52 & 43.38 & 10.18 \\
\hline L.S.D. at 0.05 & 2.70 & 0.56 & 2.73 & 1.98 & 1.02 & 2.03 & 1.54 \\
\hline
\end{tabular}


Table (2): Effect of $\mathbf{G A}_{3}$ and BA on the vegetative growth of Beaucarnea recurvata Lem. plant during the second season $(2006 / 2007)$.

\begin{tabular}{|l|c|c|c|c|c|c|c|}
\hline \multicolumn{1}{|c|}{ Treatments } & $\begin{array}{c}\text { Plant height } \\
(\mathbf{c m})\end{array}$ & $\begin{array}{c}\text { Stem } \\
\text { diameter } \\
(\mathbf{m m})\end{array}$ & $\begin{array}{c}\text { Number } \\
\text { of leaves / } \\
\text { plant }\end{array}$ & $\begin{array}{c}\text { Leaf } \\
\text { length } \\
(\mathbf{c m})\end{array}$ & $\begin{array}{c}\text { Leaf } \\
\text { width } \\
(\mathbf{m m})\end{array}$ & $\begin{array}{c}\text { Leaves } \\
\text { fresh } \\
\text { weight } \\
\mathbf{( g )}\end{array}$ & $\begin{array}{c}\text { Leaves } \\
\mathbf{d r y} \\
\text { weight } \\
(\mathbf{g})\end{array}$ \\
\hline Control & 78.33 & 13.83 & 27.22 & 44.11 & 7.72 & 33.04 & 7.85 \\
$\mathrm{GA}_{3} 200 \mathrm{ppm}$ & 106.67 & 22.12 & 28.44 & 64.83 & 12.72 & 33.92 & 9.98 \\
$\mathrm{GA}_{3} 300 \mathrm{ppm}$ & 110.72 & 17.64 & 30.83 & 60.56 & 9.56 & 56.83 & 13.97 \\
$\mathrm{GA}_{3} 500 \mathrm{ppm}$ & 120.28 & 16.72 & 35.67 & 56.33 & 9.44 & 37.63 & 9.10 \\
$\mathrm{BA} 50 \mathrm{ppm}$ & 98.00 & 19.28 & 33.17 & 69.28 & 11.67 & 41.59 & 10.44 \\
$\mathrm{BA}$ 100 ppm & 105.28 & 20.78 & 29.67 & 65.44 & 11.11 & 45.57 & 11.52 \\
BA 200 ppm & 93.83 & 21.50 & 25.00 & 55.83 & 9.89 & 31.87 & 7.48 \\
\hline L.S.D. at 0.05 & 2.86 & 1.01 & 1.51 & 2.35 & 0.95 & 2.95 & 1.56 \\
\hline
\end{tabular}

plant height and enhanced the number of leaves. Salama et al. (2002) stated that spraying fennel plants with $\mathrm{GA}_{3}$ (100 or 200 ppm) and kinetin (10 or $20 \mathrm{ppm})$ increased fresh and dry weights of fennel shoots. Hussien (2004) found that supplying Iris plants with BA at 10 or 20 ppm significantly increased the fresh weight of leaves. Ahmed et al. (2005) on Peperomia obtusifolia indicated that $\mathrm{GA}_{3}$ at $400 \mathrm{ppm}$ resulted in the heaviest fresh and dry weights. Eissa (2007) found that spraying Pelargonium zonal with BA at 10 or $20 \mathrm{ppm}$ increased fresh weight of vegetative parts. Mahmoud (2007) noticed that spraying Chasmanthe aethiopica with kinetin at 25, 50 or $75 \mathrm{ppm}$ improved fresh and dry weights of leaves.

\subsection{Chemical constituents of leaves \\ 3.2.1.Photosynthetic pigments in fresh leaves \\ 3.2.1.1. Chlorophyll (a) content:}

As shown in Table (3) the data on chlorophyll (a) show that treating the plants with $\mathrm{GA}_{3}$ or BA increased chlorophyll (a) content over the control plants in the second season, while in the first one they decreased it except the concentration of $\mathrm{BA}$ at $50 \mathrm{ppm}$. Raising the concentration of BA decreased chlorophyll (a) content in the two seasons. The highest value of chlorophyll (a) resulted from BA at $50 \mathrm{ppm}(0.33$ and $0.42 \mathrm{mg} / \mathrm{g}$ $\mathrm{FW}$, respectively) in both seasons. The least content of chlorophyll (a) $(0.27 \mathrm{mg} / \mathrm{g} \mathrm{FW})$ was formed as a result of supplying the plants with BA at 200 ppm in the first season. While, in the second one the control plants had the least amount of chlorophyll (a) $(0.25 \mathrm{mg} / \mathrm{g}$ FW). Similar results had been reported by Farid et al. (1999) who found that foliar application of kinetin at $50 \mathrm{ppm}$ increased chlorophyll a content in the leaves of sweet marjoram. Also, Kanddeel et al. (1998) pointed out that chlorophyll a content in the leaves of Crinum or Hemerocallis was increased due to kinetin at various levels (25, 50 or $75 \mathrm{ppm}$ ). Khafagy et al. (2002) on fennel indicated that chlorophyll (a) was increased due to kinetin (10 or $20 \mathrm{ppm}$ ), while the treatment of $\mathrm{GA}_{3}$ at 100 or $200 \mathrm{ppm}$ decreased it.

\subsubsection{Chlorophyll (b) content}

Data presented in Table (3) indicate that the highest chlorophyll (b) content in the two seasons $(0.25$ and $0.27 \mathrm{mg} / \mathrm{g} \mathrm{FW}$, respectively) was detected in the leaves of the control plants. The plants treated with BA at $200 \mathrm{ppm}$ had the least content of chlorophyll (b) $(0.17$ and $0.15 \mathrm{mg} / \mathrm{g} \mathrm{FW}$, in the first and second seasons, respectively). All the treatments of $\mathrm{GA}_{3}$ and $\mathrm{BA}$ significantly decreased chlorophyll (b) content.

\subsubsection{Total chlorophylls $(a+b)$ content}

From the data shown in Table (3) it can be noticed that the highest content of total chlorophylls $(\mathrm{a}+\mathrm{b})$ in the first season $(0.57$ $\mathrm{mg} / \mathrm{g} \mathrm{FW}$ ) was found in the control plants. This increase may be due to the increase in chlorophyll (b) content. In the second season, treating the plants with $\mathrm{GA}_{3}$ at $500 \mathrm{ppm}$ or $\mathrm{BA}$ at $50 \mathrm{ppm}$ resulted in more accumulation of total chlorophylls $(0.58$ and $0.57 \mathrm{mg} / \mathrm{g}$ $\mathrm{FW}$, respectively). The least amount ( 0.44 and $0.42 \mathrm{mg} / \mathrm{g} \mathrm{FW}$ ) was determined in the leaves of the plants treated with $200 \mathrm{ppm}$ BA in the two seasons. In this respect, Farahat et al. (2002) on fennel found that BA at 50 or 100 ppm increased significantly the total chlorophylls. Eissa (2007) found that spraying 
Pelargonium zonal with BA at 10 or 20 ppm increased the total chlorophylls.

\subsubsection{Carotenoids content}

The data in Table (3) reveal that the highest content of carotenoids $(0.29 \mathrm{mg} /$ $\mathrm{g} \mathrm{FW}$ ) was due to treating the plants with significantly increased the percentage of the total carbohydrates compared to untreated plants in the two seasons. Increasing the rate of $\mathrm{GA}_{3}$ decreased the accumulation of total carbohydrates in the leaves. The highest total carbohydrates percentages (27.18 and 26.00

Table (3): Effect of $\mathrm{GA}_{3}$ and $\mathrm{BA}$ on photosynthetic pigments ( $\mathrm{mg} / \mathrm{g}$ fresh weight) in the leaves of Beaucarnea recurvata Lem. plant during the two successive seasons of 2005 / 2006 and $2006 / 2007$.

\begin{tabular}{|c|c|c|c|c|c|c|c|c|}
\hline \multirow{2}{*}{ Treatments } & \multicolumn{2}{|c|}{ Chlorophyll (a) } & \multicolumn{2}{c|}{ Chlorophyll (b) } & \multicolumn{2}{c|}{ Total chlorophylls } & \multicolumn{2}{c|}{ Carotenoids } \\
\cline { 2 - 8 } & $\begin{array}{c}\text { First } \\
\text { season }\end{array}$ & $\begin{array}{c}\text { Second } \\
\text { season }\end{array}$ & $\begin{array}{c}\text { First } \\
\text { season }\end{array}$ & $\begin{array}{c}\text { Second } \\
\text { season }\end{array}$ & $\begin{array}{c}\text { First } \\
\text { season }\end{array}$ & $\begin{array}{c}\text { Second } \\
\text { season }\end{array}$ & $\begin{array}{c}\text { First } \\
\text { season }\end{array}$ & $\begin{array}{c}\text { Second } \\
\text { season }\end{array}$ \\
\hline Control & 0.32 & 0.25 & 0.25 & 0.27 & 0.57 & 0.52 & 0.26 & 0.19 \\
$\mathrm{GA}_{3} 200 \mathrm{ppm}$ & 0.30 & 0.29 & 0.18 & 0.18 & 0.48 & 0.47 & 0.25 & 0.19 \\
$\mathrm{GA}_{3} 300 \mathrm{ppm}$ & 0.31 & 0.38 & 0.19 & 0.23 & 0.50 & 0.51 & 0.29 & 0.13 \\
$\mathrm{GA}_{3} 500 \mathrm{ppm}$ & 0.31 & 0.35 & 0.19 & 0.23 & 0.50 & 0.58 & 0.28 & 0.17 \\
BA 50 ppm & 0.33 & 0.42 & 0.20 & 0.15 & 0.53 & 0.57 & 0.25 & 0.13 \\
BA 100 ppm & 0.30 & 0.32 & 0.18 & 0.19 & 0.48 & 0.51 & 0.28 & 0.13 \\
BA 200 ppm & 0.27 & 0.27 & 0.17 & 0.15 & 0.44 & 0.42 & 0.28 & 0.18 \\
\hline L.S.D. at & 0.01 & 0.04 & 0.02 & 0.03 & 0.03 & 0.04 & 0.02 & 0.01 \\
0.05 & 0.027 & & & & & & \\
\hline
\end{tabular}

$\mathrm{GA}_{3}$ at $300 \mathrm{ppm}$ in the first seasons. Meanwhile, the plants received $\mathrm{GA}_{3}$ at $200 \mathrm{ppm}$ or BA at $50 \mathrm{ppm}$ had the least amount of carotenoids $(0.25 \mathrm{mg} / \mathrm{g} \mathrm{FW})$. In the second season, the control plants and those received $\mathrm{GA}_{3}$ at $200 \mathrm{ppm}$ had the highest content of carotenoids (0.19 $\mathrm{mg} / \mathrm{g} \mathrm{FW}$ ). The least content of carotenoids (0.13 mg / $\mathrm{g}$ FW) was determined in the leaves of the plants treated with $\mathrm{GA}_{3}$ at $300 \mathrm{ppm}$ and $\mathrm{BA}$ at 50 or 100 ppm.

\subsubsection{Total carbohydrates percentage}

The data on total carbohydrates contents as shown in Table (4) show that all the treatments of the growth regulators
$\%$, respectively) were formed in the plants treated with $\mathrm{GA}_{3}$ at $200 \mathrm{ppm}$. The least percentage of total carbohydrates (22.42 and $22.75 \%$, respectively) was detected in the control plants. Similar results were obtained by Abdel-Wahid and Manoly (2003) who mentioned that $\mathrm{GA}_{3}$ at $50 \mathrm{ppm}$ increased the total carbohydrates in the leaves of Ficus benjamina. Hussien (2004) found that supplying Iris plants with BA at 10 or $20 \mathrm{ppm}$ significantly increased the total carbohydrates Eissa (2007) stated that spraying Pelargonium zonal with BA at 10 or $20 \mathrm{ppm}$ increased the total sugars content in the leaves.

\subsubsection{Nitrogen percentage}

Nitrogen percentage as affected by the growth regulators is presented in Table (4), in

Table (4): Effect of $\mathrm{GA}_{3}$ and $\mathrm{BA}$ on total carbohydrates, $\mathrm{N}, \mathrm{P}$ and $\mathrm{K}$ percentages in the leaves of Beaucarnea recurvata Lem. plants during the two successive seasons of 2005 / 2006 and 2006 / 2007.

\begin{tabular}{|l|c|c|c|c|c|c|c|c|}
\hline \multirow{2}{*}{ Treatments } & \multicolumn{2}{|c|}{$\begin{array}{c}\text { Total carbohydrates } \\
\text { \% }\end{array}$} & \multicolumn{2}{c|}{ Nitrogen \% } & \multicolumn{2}{c|}{$\begin{array}{c}\text { Phosphorus \% } \\
\text { (D.W) }\end{array}$} & \multicolumn{2}{|c|}{ Potassium \% (D.W) } \\
\cline { 2 - 10 } & $\begin{array}{c}\text { First } \\
\text { season }\end{array}$ & $\begin{array}{c}\text { Second } \\
\text { season }\end{array}$ & $\begin{array}{c}\text { First } \\
\text { season }\end{array}$ & $\begin{array}{c}\text { Second } \\
\text { season }\end{array}$ & $\begin{array}{c}\text { First } \\
\text { season }\end{array}$ & $\begin{array}{c}\text { Second } \\
\text { season }\end{array}$ & $\begin{array}{c}\text { First } \\
\text { season }\end{array}$ & $\begin{array}{c}\text { Second } \\
\text { season }\end{array}$ \\
\hline Control & 22.42 & 22.75 & 1.46 & 1.10 & 0.22 & 0.24 & 1.90 & 1.89 \\
$\mathrm{GA}_{3}$ 200 ppm & 27.18 & 26.00 & 2.06 & 1.70 & 0.19 & 0.21 & 1.93 & 1.91 \\
$\mathrm{GA}_{3}$ 300 ppm & 24.00 & 25.67 & 1.92 & 1.15 & 0.23 & 0.23 & 1.99 & 1.95 \\
$\mathrm{GA}_{3}$ 500 ppm & 23.75 & 23.63 & 1.59 & 0.90 & 0.25 & 0.28 & 1.93 & 1.92 \\
$\mathrm{BA} \mathrm{50} \mathrm{ppm}$ & 23.58 & 25.17 & 2.07 & 1.20 & 0.24 & 0.20 & 1.98 & 1.97 \\
BA 100 ppm & 27.00 & 25.63 & 2.10 & 1.20 & 0.24 & 0.21 & 2.06 & 2.02 \\
BA 200 ppm & 22.88 & 25.25 & 2.23 & 1.24 & 0.24 & 0.22 & 1.94 & 1.92 \\
\hline L.S.D. at 0.05 & 1.07 & 1.21 & 0.04 & 0.18 & 0.02 & 0.03 & 0.06 & 0.02 \\
\hline
\end{tabular}


both seasons, all the treatments increased nitrogen percentage over the control except the treatment of $\mathrm{GA}_{3}$ at $500 \mathrm{ppm}$ in the second season. In the first season, the highest accumulation of nitrogen $(2.23 \%$,) was detected in the plants treated with BA at 200 ppm, while the least percentage $(1.46 \%)$ was found in the control plants. In the second season, application the plants with $\mathrm{GA}_{3}$ at 200 ppm resulted in the formation of the highest percentage of nitrogen $(1.70 \%)$. The least percentage of nitrogen $(0.90 \%)$ was determined in the plants treated with $\mathrm{GA}_{3}$ at $500 \mathrm{ppm}$.

\subsubsection{Phosphorus percentage}

The recorded data for phosphorus percentage in Beaucarnea recurvata plants (Table 4) reveal that in the two seasons, the greatest amount of $\mathrm{P}(0.25$ and $0.28 \%$, respectively) was determined in the plants received $\mathrm{GA}_{3}$ at $500 \mathrm{ppm}$. The least percentage $(0.19 \%)$ was found in the plants treated with $\mathrm{GA}_{3}$ at $200 \mathrm{ppm}$ in the first season. In the second one, BA at $50 \mathrm{ppm}$ reduced the accumulation of $\mathrm{P}$ to the least percentage $(0.20 \%)$. There was insignificant difference among BA treatments in both seasons.

\subsubsection{Potassium percentage}

Data shown in Table (4) indicate that in both seasons, all the treatments led to an increase in potassium percentage over the control plants. The greatest percentage of potassium in both seasons (2.06 and $2.02 \%$, respectively) was determined in the plants treated with BA at $100 \mathrm{ppm}$. The least percentages (1.90 and $1.89 \%$ in both seasons, respectively) were found in the control plants.

These results are in harmony with those obtained by Abdel-Wahid and Manoly (2003) who mentioned that $\mathrm{GA}_{3}$ increased $\mathrm{N}$ and $\mathrm{P}$ content in the leaves of Ficus benjamina. Farahat et al. (2002) on fennel and Hussien (2004) on Iris, found that BA at various concentrations significantly increased $\mathrm{N}$ and $\mathrm{P}$ $\%$ in the leaves.

It can be recomneded that accelerate the growth of Beaucarnea recurvata plant it hould be treated with $\mathrm{GA}_{3}$ at the rate of 400 ppm as soil drench.

\section{REFERENCES}

Abdel-Wahid S.M.K. and Manoly N.D. (2003). Effect of $\mathrm{GA}_{3}$ on Ficus benjamina L. seedlings. Proc. $1^{s t}$ Egypt. \& Syr. Conf. for Agric. \& Food, El-Minia: Dec. 8 - 11, 2003, Vol. 1 No. 1 (145-160).

Ahmed G.E.F., Abdel-Wahid S.M.K. and Sabh A.Z.E. (2005). Effect of paclobutrazol and gibberellic acid on Peperomia obtusifolia (L.) A. Dietr. plant. 1- Vegetative growth. The $6^{\text {th }}$ Arabian Conf. for Hort., Ismailia, Egypt: March 20 - 22, 2005 (65 74).

Arteca R.N. (1996). Plant Growth Substances Principles and Application. Chapman \& Hall Press.

Cline M.G. (1988). Apical dominance. Bot. Rev., 57: 318 - 358.

Dwivedi M.P., Negi K.S., Jindal K.K. and Rana H.S. (1999). Effect of bioregulators on vegetative growth of strawberry. Scientific Horticulture, 6: 79 - 84. (Hort. Abst., 70: 1046).

Eissa T.E.A. (2007). Physiological Studies on Handling of Pelargonium zonal, L., Chrysanthemum leucanthemum, L. and Rudbeckia tricolor, L. Ph.D. Thesis, Fac. Agric. Kafr El-Sheikh, Tanta Univ.

Farahat M.M., Habba E.E. and Rashad ElSh.M. (2002). Physiological response of fennel to tryptophan, naphthalene acetic acid and benzyladenine treatments in sandy soil. Egypt. J. Appl. Sci., 17 (11): 642 - 633.

Farid M.R., Habba E.A and Mahmoud H.F. (1999). Physiological and biochemical response of sweet marjoram (Majorana hortensis L.) to foliar kinetin application and gamma radiation. Minufiya J. Agric. Res., 24 (1): $251-260$.

Herbert D., Philipps P.J. and Strange R.E. (1971). Determination of total carbohydrates. Methods in Microbiol., 58: 209 - 344.

Hussien H.S.M. (2004). Physiological Studies on Iris Plant. M. Sc. Thesis, Fac. Agric. Cairo Univ.

Kanddeel Y.M., Nofal E.M.S., El-Tarawy, M.A. Auda, M.S. and Shahin S.M. (1998). Effect of kinetin and greenzit on Crinum longifolium, Thunb and Hemerocallis aurantiaca, Baker plants. II- Effect on bulbs productivity and plants chemical 
analysis. The $2^{\text {nd }}$ Conf. of Orn. Hort. Ismailia, Egypt, Oct. 24 - 26, 1998 $(199-215)$.

Khafagy M.A., Salama S.M., El-Hadidi M.S. and Ismail S.I.I. (2002). Effect of some growth substances on physiological characters and yield of fennel plants. The $2^{\text {nd }}$ Inter. Conf. Hort. Sci., 10 - 12 Sept. 2002, Kafr El-Sheikh, Tanta Univ., Egypt, (930 939).

Leopold A.C. and Kriedmann P.E., (1980). Plant Growth and Development. Mc Graw-Hill Publishing Company Ltd. London, $3^{\text {rd }}$ Ed.

Mahmoud A.M.A. (2007). Response of Chasmanthe aethiopica (L.) N.E.Br. plants to foliar spray with kinetin and kristalon. J. Agric. Sci. Mansoura Univ., 32 (7): 5517 - 5528.

Mok D.W. and Mok M.C. (2001). Cytokinin metabolism and action. Plant Mol. Biol., 52, 89-118.

Nofal E.M.S., El-Tarawy M.A., Kanddeel Y.M., Auda M.S. and Shahin S.M. (1998). Effect of kinetin and greenzit on Crinum longifolium, Thunb and Hemerocallis aurantiaca, Baker plants. I- Effect on vegetative growth and flowering. The $2^{\text {nd }}$ Conf. of Orn. Hort. Ismailia, Egypt, Oct. 24 - 26, $1998(187-198)$.

Piper C.S. (1947). Soil and Plant Analysis. p. 258 - 275. Univ. of Adelaide, Adelaide, Australia.

Pregl F. (1945). Quantitative Organic Microanalysis $4^{\text {th }}$ Ed. Church. London.

Raven P. H., Evert, R. F., and Eichhorn, S. E. (1992). Biology of Plants. New York: Worth. p. $545-572$.

Runkova L.V. (1977). Interaction between exogenous and endogenous growth regulators as exemplified on ornamental plants. Bulleten Clavnoge Botanicheskog Sada, 106: $62-70$.
Sacks R.M. (1961). Gibberellin, auxin and growth retardant effect upon cell division and shoot histogenesis. Adv. Chem., 28: 49 - 58.

Salama S.M., Khafagy M.A., El-Hadidi M.S. and Ismail S.I.I. (2002). Morphological and anatomical studies on fennel plants as affected by some growth substances. The $2^{\text {nd }}$ Inter. Conf. Hort. Sci., 10 - 12 Sept. 2002, Kafr El-Sheikh, Tanta Univ., Egypt, $(473-483)$.

Salisbury F. B. and Ross, C. W. (1992). Plant Physiology. Belmont, CA: Wadsworth. p. $357-407,531-548$.

Saric M., Kastrori R., Curic R., Cupina T. and Geric I. (1967). Chlorophyll Determination. Univerzit et U Noveon Sadu. Praktikum iz Fiziologize Bilijaka Beograd Haucna Anjiga. 215 pp.

Snedecor G.W. and Cochran W.G. (1982). Statistical Methods, $7^{\text {th }}$ Ed. The Iowa State Univ., Press. Iowa, USA, 507 pp.

Srivastava L.M. (2002). Plant Growth and Development Hormones and Environment. Academic Press, London. p. 191 - 204

Staples G.W. and Herbst D.R. (1996). Nomenclature changes affecting cultivated plants. Journal of horticultural taxonomy, 23: 171.

Troug E. and Meyer R.H. (1939). Improvement in deiness colorimetric methods for phosphorus and arsenic. Ind. Eng. Chem. Anal. Ed., (1): 136 139.

Wareing P.F. and Phillips I.D.J.. (1973). The Control of Growth and Differentiation in Plants. Pergamon Press Ltd. Oxford, UK. 293pp. 


\section{باستخدام بعض منظمات النموBeaucanea recurvata LEM الإسراع من نمو نباتات (الزلوع)}

$$
\text { صفوت مصطفى كامل عبد الواحد و سهام جاد الكريم سويفى }
$$

قسم بحوث نباتات الزينة وتتسيق الحدائق ـ معهد بحوث البساتين - مركز البحوث الزر اعية

$$
\text { الجيزة - مصر - معر بحر }
$$

\section{ملخص}

يهدف هذا البحث إلى دراسة استجابة نباتات البوكارنبا ريكورفاتا (الزلوع) لإضافة الإنة حمض الجبريالليك و البنزيل

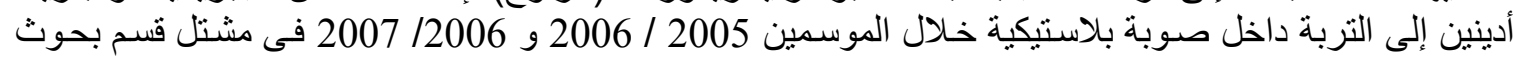

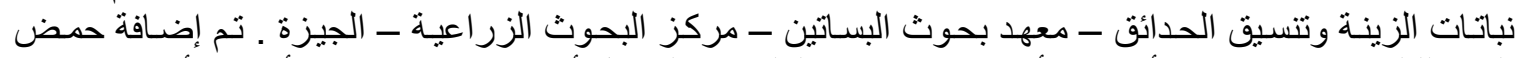

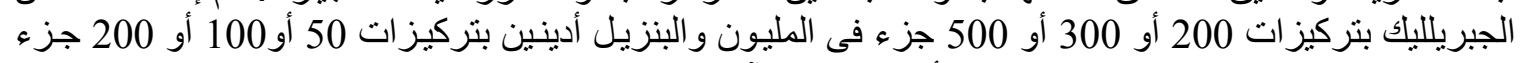

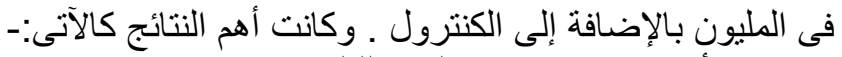

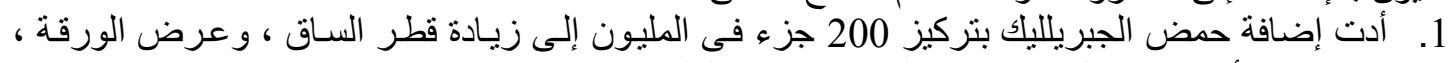

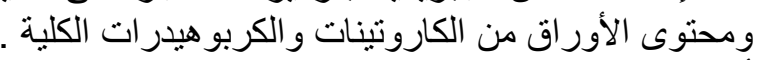

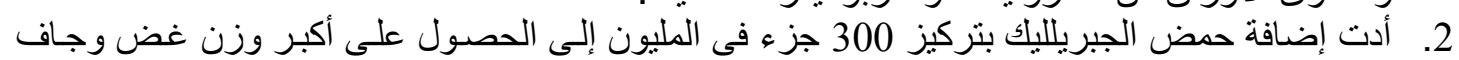
للأور اق ـ ألمافة

3. أدت المعاملة بحمض الجبريللبك بتركيز 500 جزء فـى في المليون إلى زيادة ارتفاع النبات ، و عدد الأوراق /

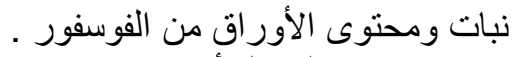
4. وكان لإضافة البنزيل أدينين بتركيز 50 جزء فـ في المليون تأثير فى زيادة طول الورقة ومحتوى الأوراق من كلوروفيل الإصناف البنز

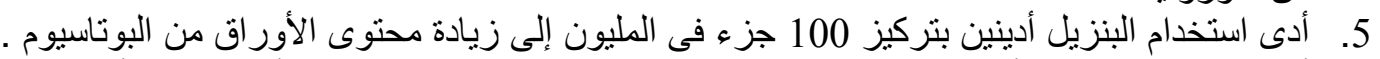

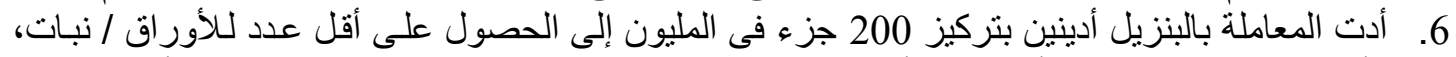

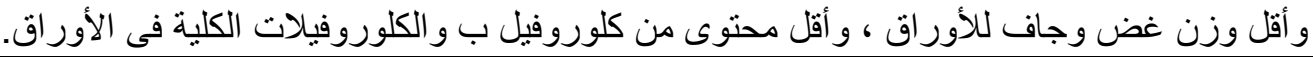

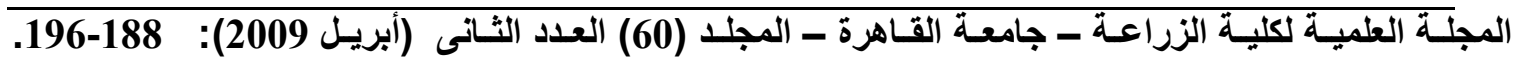


